\title{
Current Status of Faculty Development of Medical Sciences Universities in Iran: A Qualitative Study
}

\author{
Shafigheh Mohammaditabar ${ }^{1,{ }^{*}}$, Abbas Abbaspour ${ }^{2}$ and Ali Khorsandi Taskoh ${ }^{2}$ \\ ${ }^{1}$ Faculty Member of School of Nursing and Midwifery, Shahed University, Tehran, Iran \\ ${ }^{2}$ Faculty of Psychology and Educational Sciences, Allameh Tabataba'i University, Tehran, Iran \\ "Corresponding author: Faculty Member of School of Nursing and Midwifery, Shahed University, Tehran, Iran. Email: sh.mohammaditabar@gmail.com
}

Received 2019 July 13; Revised 2019 November 04; Accepted 2019 November 16.

\begin{abstract}
Background: Higher education institutions and medical universities always need developed faculties to reach their objectives, thus they need plans for empowering the professors. Hence, it is necessary for them to seek and apply the views of the experts on development.

Objectives: The present qualitative study aimed to analyze development of faculty members of universities of medical sciences in Iran based on different views of experts.

Methods: Some experts in the field of medical educational development were selected using purposive and snowball sampling methods until reaching the theoretical saturation, and underwent semi-structured interviews. The interviews were recorded and transcribed verbatim, and analyzed through qualitative content analysis.

Results: The analysis of transcripts yielded 321 initial codes that were classified and summarized according to conceptual similarities and differences. Subthemes of research, educational, leadership and management, specialty, ethical and individual dimensions were observed for the faculty development of medical sciences universities.

Conclusions: According to the results of the study, managers and officials are recommended to adopt a comprehensive look at the faculty development plans and consider all its aspects.
\end{abstract}

Keywords: Faculty, Universities, Education, Medical

\section{Background}

Faculty development and the effective implementation of their related programs are not only an important aspect of creating change, but also a serious challenge in higher education institutions and universities. Faculty development currently has become an important part of higher education, especially in universities of medical sciences (1). Faculty development has been defined as the wide range of activities that institutions apply to support the roles of faculty members (2). Over the past 30 years, the vision of medical education has gradually improved for various reasons, like emerging changes, health standards, new technologies, and new approaches in education, which is why current professors drastically differ from the teachers who taught them (3). There are different initiatives on the development of faculty members in the health profession, and there is a growing interest in both research and practice in this field (4). Given the challenges and the opportunities faculty members, faculties and universities may experience in future, faculty mem- bers should be addressed with a new approach (5). Furthermore, faculty members in universities of medical sciences have multifaceted roles and specific challenges, and they have no educational experience for their role as faculty members (6). In universities of medical sciences, educational development centers (EDCs) and educational development offices (EDO) have been established to enhance education and other scientific activities of faculty members (7-9).

Moreover, it is necessary for medical education practitioners to use the views of scholars on the development of faculty members and to provide appropriate strategies for empowering the faculty members of universities of medical sciences.

\section{Objectives}

The present qualitative study aimed to evaluate the development of faculty members in Iran, based on the views of the experts in the field of education development through in-depth interviews. 


\section{Methods}

Some experts in the field of medical educational development were selected and underwent semi-structured interviews by purposive and snowball sampling methods until reaching the theoretical saturation. All participants were affiliated with the faculty development field in universities of medical sciences or had relevant books or papers published or research projects in this field. During the interview process, we had an opportunity to see the feelings and reach the opinions of the interviewees on the research topic. Demographic information was collected using a questionnaire. After receiving consent, the participants were assured that their information would be kept confidential and that they could leave whenever they wished. The interviews took place in person at their workplace at a convenient time for the participants. The interviews lasted roughly 35 - 45 minutes. At the start of the interview, the following questions were asked based on the objectives of the study: "What does faculty development mean to you?", "What are the goals of the faculty development?", "What are the aspects of faculty development in your opinion?". Then, after the answers were provided, the questions continued as "Can you explain more?" or "You mean...". The interviews were fully recorded and transcribed verbatim. Then the interviews were read lineby-line and analyzed. The codes were converted into categories, and the initial categories were formed. Eventually, all categories and sub-categories were saturated; i.e., no new data could be extracted any longer.

\section{Results}

The results showed that the mean age and work experience of the interviewees were 48 years and 19 years, respectively. Additionally, two (18.18\%) interviewees were professors, five (45.45\%) were associate professors, three (27.27\%) were assistant professors and one was not a faculty member. Moreover, two (18.18\%) were women and nine (81.81\%) were men.

A total of 321 initial codes were extracted from the interviews. Then the codes were summarized, and formed three themes and ten categories (Table 1). Categories and subcategories of faculty development are derived (Table 2).

\section{Discussion}

According to the results, two kinds of definitions are deduced from 'faculty development'. The first is 'the faculty members' empowerment in relation to their professional roles'; the second definition that experts accept is 'achievement of perfection and flourishing'. Some researchers define the development of faculty members, by all activities designed and implemented to improve faculty performance in their professional lives $(2,10)$.

The goals stated for faculty development can be divided into the university and individual goals. Most of the individual goals are in line with the university goals set for the faculty members' promotion. Some researches consider faculty development as all the activities designed and implemented to improve the performance of faculty members in all aspects of work life and professionalism (11$14)$, and some researchers have clearly identified individual goals in other aspects of faculty members' life $(4,15)$.

Experts suggest the following six aspects in the development of the faculty members of universities of medical sciences: educational, research, individual, specialized, leadership and management, and ethical dimensions.

\subsection{Educational Aspect}

It is the first dimension that the participants mention. Emphasized by the medical universities and EDCs, educational dimension is often used to describe the faculty members' activities and programs. Educational development stresses courses and curricula and helps to improve faculty members' skills to design better educational programs to empower students and prepare the materials and facilities needed for learning by members of the board. It includes activities that ease students' learning, provide educational materials and redefine the curriculum $(13,16,17)$.

In universities of medical sciences, most faculty members do not have a specific educational experience and they have not been trained for that purpose during their studies, which is why it seems more important (7).

Researchers suggest teaching activities $(4,8,11)$, designing courses $(4,8,11,17,18)$, student counseling and assessment, educational strategies, educational software production and educational leadership (4, 8, 16, 19-23), in this aspect.

\subsection{Research Aspect}

Research development is about a set of abilities and skills related to the research mission and the research role of the faculty members (14). Some researchers have separately stated research dimension as one of the aspects of faculty development $(3,4,7,14,15,24)$. However, other researchers have placed the research dimension in the professional dimension $(17,19,25)$.

\subsection{Individual Aspect}

Individual development stresses the dimensions of attitude and increases the beliefs and values of the faculty 


\begin{tabular}{|c|c|c|c|}
\hline Themes & Categories & Code Samples & Participants \\
\hline \multirow{2}{*}{$\begin{array}{l}\text { Development } \\
\text { definition }\end{array}$} & $\begin{array}{l}\text { Empowerment in relation to their professional } \\
\text { roles }\end{array}$ & $\begin{array}{l}\text { Faculty development in fact means that we want to train powerful } \\
\text { teachers in the field of medical education. }\end{array}$ & M 10 \\
\hline & Development means flourishing and perfection & $\begin{array}{l}\text { Development means to reach perfection, but from inside out, } \\
\text { development comes from inside and not by adding something from } \\
\text { the outside. }\end{array}$ & M 6 \\
\hline \multirow{2}{*}{$\begin{array}{l}\text { Development } \\
\text { goals }\end{array}$} & $\begin{array}{l}\text { There are goals both for individuals and faculty } \\
\text { members in advancement }\end{array}$ & $\begin{array}{l}\text { These are the goals of the university to improve faculty members in } \\
\text { these areas while faculty members have their own personal goal for } \\
\text { improvement. }\end{array}$ & M 4 \\
\hline & Objectives are the goals of the university & $\begin{array}{l}\text { I think the university is directing the development of faculty. They } \\
\text { say there are some mandatory workshops such as empowerment } \\
\text { workshops and if they do not participate, they will not be } \\
\text { promoted.... }\end{array}$ & M 10 \\
\hline \multirow{6}{*}{ Aspects } & Research aspect & $\begin{array}{l}\text { The area of research is fine and we can even say that it has been over } \\
\text { invested; but it will need more attention in the future. }\end{array}$ & M 9 \\
\hline & Education aspect & $\begin{array}{l}\text { A faculty member can develop as a professor or a teacher especially } \\
\text { in education aspect. }\end{array}$ & M 6 \\
\hline & Leadership and management aspect & $\begin{array}{l}\text { I should say that someone in management position should be able } \\
\text { to act as a leader. }\end{array}$ & M3 \\
\hline & Professional aspect & $\begin{array}{l}\text { We see the professional aspect when it comes to completing the } \\
\text { specialty itself. }\end{array}$ & M3 \\
\hline & Ethical aspect & Another responsibility is being ethics-oriented. & M 7 \\
\hline & Individual aspect & $\begin{array}{l}\text { The least that a university has to do is to make the groundwork for a } \\
\text { faculty member to know their capabilities as a person. }\end{array}$ & M3 \\
\hline Themes & Categories & Sub-Categories & \\
\hline \multirow{3}{*}{$\begin{array}{l}\text { Faculty } \\
\text { development's } \\
\text { focus on the } \\
\text { organization }\end{array}$} & Organizational culture & \multicolumn{2}{|c|}{$\begin{array}{l}\text { Improving teamwork spirit, strengthening spiritual motivation, creating } \\
\text { constructive human relationships, axial justice, and etc... }\end{array}$} \\
\hline & Policies and laws & \multicolumn{2}{|c|}{$\begin{array}{l}\text { Promotion of human resources, decentralization in higher education, } \\
\text { designing new models of recruitment, evaluation and promotion of faculty, } \\
\text { and etc... }\end{array}$} \\
\hline & Structures and supports & \multicolumn{2}{|c|}{$\begin{array}{l}\text { Facilitating communication and interactions between universities and } \\
\text { relevant educational centers, increasing access to scientific resources, } \\
\text { providing faculty welfare, and etc... }\end{array}$} \\
\hline \multirow{6}{*}{$\begin{array}{l}\text { Faculty } \\
\text { development's } \\
\text { focus on the } \\
\text { individual }\end{array}$} & Individual dimension & \multicolumn{2}{|c|}{$\begin{array}{l}\text { Discipline, scientific collaboration with others, time management, balances } \\
\text { between work and personal life, and etc... }\end{array}$} \\
\hline & Specialty dimension & \multicolumn{2}{|c|}{$\begin{array}{l}\text { Providing health services and health promotion, training medical science } \\
\text { specialists, off-campus specialized counseling, and etc... }\end{array}$} \\
\hline & Educational dimension & \multicolumn{2}{|c|}{ Teaching, student evaluation, production of educational software, etc... } \\
\hline & Research dimension & \multicolumn{2}{|c|}{$\begin{array}{l}\text { Implementation of research projects, reviewing articles, publishing and } \\
\text { translating books, and etc... }\end{array}$} \\
\hline & Leadership and management dimension & \multicolumn{2}{|c|}{$\begin{array}{l}\text { Accepting responsibility in the headquarters areas of the ministry of health, } \\
\text { treatment and medical education, accepting responsibility for departments, } \\
\text { hospitals and universities, and etc... }\end{array}$} \\
\hline & Ethical dimension & \multicolumn{2}{|c|}{$\begin{array}{l}\text { Observing human ethics, professional ethical compliance, Islamic values, and } \\
\text { etc... }\end{array}$} \\
\hline
\end{tabular}

members. Individual development of the faculty members refers to the faculty members' characteristics and capacities. Development in the individual dimension usually focuses on strategies and experiences which improve the individual and interpersonal effectiveness of faculty members $(19,26)$.

\subsection{Specialty Aspect}

Special service development is a set of competencies that faculty members should possess in order to provide specialized services to outside stakeholders. Some of the indices in this regard include skills in the provision of specialized services, technology skills, information technol- 
ogy, communication between university and industry, and providing professional and specialized advice to society $(18,19)$.

\subsection{Leadership and Management Aspect}

Faculty members need some programs regarding management and leadership skills, especially for members wishing to join corporate offices. Although these skills are essential, they are often less emphasized in faculty development (27).

As the faculty development shapes in line with duties at the university and some of the main duties are in the field of executive and managerial activities, management and leadership should be considered separately. Furthermore, because university management is different from hospital management, both sub-categories should be addressed separately.

\subsection{Ethical Aspect}

Observing ethics is one of the most important variables in the success of an organization. Currently, the world is returning to rationality and ethics. This approach A mostly affects the majors and professions leading in service provision to humans $(28,29)$.

In the present study, the majority of scholars believed that ethics should be present in all aspects of faculty development, and it cannot be considered separate from other aspects. We should admit that all aspects of the development of the faculty members interact with one another and cannot be separated $(9,26)$.

\subsection{Conclusions}

The results of this study show that medical universities of Iran should consider other aspects of faculty members, including: individual, organizational, and ethical dimensions and specialized services instead of attending only to the educational and research dimensions in the faculty's upcoming programs. Faculty members need constant promotion and development. Meanwhile, they have their own personal goals and expectations. They also have social needs and relations.

It is suggested that a comprehensive faculty development program be developed at medical universities with the aim to upgrade and update faculty members' abilities, by supporting the program, considering all aspects of faculty development and the opinions of faculty members. Failing to believe in faculty development programs and failing to identify faculty members' needs and priorities demotivates faculty members and discourages them from participating in development programs. As a result, such programs will not be successful.

\section{Acknowledgments}

Hereby, the researchers appreciate all those who helped in the study.

\section{Footnotes}

Authors' Contribution: All authors contributed in all part of the study.

Conflict of Interests: The authors are declared is no conflict of Interests.

Funding/Support: This article was a self-fund study by the authors.

\section{References}

1. Guglielmo BJ, Edwards DJ, Franks AS, Naughton CA, Schonder KS, Stamm PL, et al. A critical appraisal of and recommendations for faculty development. Am J Pharm Educ. 2011;75(6):122 doi: 10.5688/ajpe756122. [PubMed: 21931460]. [PubMed Central: PMC3175674].

2. Centra JA. Types of faculty development programs. J High Educ. 1978;49(2):151. doi: 10.2307/1979280.

3. Guraya SY, Chen S; Bilal. The impact and effectiveness of faculty development program in fostering the faculty's knowledge, skills, and professional competence: A systematic review and meta-analysis. Saudi J Biol Sci. 2019;26(4):688-97. doi: 10.1016/j.sjbs.2017.10.024. [PubMed: 31048993]. [PubMed Central: PMC6486500].

4. Steinert Y. Faculty development in the health professions: A focus on research and practice. Innovation and change in professional education. 11. Springer, Dordrecht; 2014. doi: 10.1007/978-94-007-7612-8.

5. McKee CW, Johnson M, Ritchie WF, Tew WM. The breadth of current faculty development: Practitioners' perspectives: New directions for teaching and learning. John Wiley \& Sons; 2013.

6. Moore JE, Pinsky MR. Faculty development for fellows: Developing and evaluating a broad-based career development course for critical care medicine trainees. J Crit Care. 2015;30(5):1152 e1-6. doi: 10.1016/j.jcrc.2015.05.032. [PubMed: 26129986].

7. Mohammaditabar S, Abbaspour A, Khorsandi Taskouh A. The components of the development of faculty members at universities of medical sciences in Iran and the world: A systematic review. Educ Res Med Sci. 2018;7(2). doi: 10.5812/erms.81735.

8. Amundsen C, Wilson M. Are we asking the right questions? Rev Educ Res. 2012;82(1):90-126. doi: 10.3102/0034654312438409.

9. O'Sullivan PS, Irby DM. Reframing research on faculty development. Acad Med. 2011;86(4):421-8. doi: 10.1097/ACM.0b013e31820dc058. [PubMed: 21346505].

10. Damp JB, Dewey CM, Wells Q, Horn L, Kroop SF, Mendes L. Faculty development on clinical teaching skills: An effective model for the busy clinician. J Med Educ Curric Dev. 2016;3. doi: 10.4137/JMECD.S40798. [PubMed: 29349327]. [PubMed Central: PMC5757630].

11. Steinert Y, Mann K, Anderson B, Barnett BM, Centeno A, Naismith L, et al. A systematic review of faculty development initiatives designed to enhance teaching effectiveness: A 10-year update: BEME Guide No. 40. Med Teach. 2016;38(8):769-86. doi: 10.1080/0142159X.2016.1181851. [PubMed: 27420193]

12. Abu-Rish Blakeney E, Pfeifle A, Jones M, Hall LW, Zierler BK. Findings from a mixed-methods study of an interprofessional faculty development program. I Interprof Care. 2016;30(1):83-9. doi: 10.3109/13561820.2015.1051615. [PubMed: 26576839]. 
13. Lo W, Lin Y, Pan Y, Wu Y, Hsieh M. Faculty development program for general medicine in Taiwan: Past, present, and future. Tzu Chi Medical Journal. 2014;26(2):64-7. doi: 10.1016/j.tcmj.2014.05.002.

14. Kamel AMF. Role of faculty development programs in improving teaching and learning. Saudi J Oral Sci. 2016;3(2):61. doi: 10.4103/16586816.188073.

15. Niemi H. Teacher professional development in Finland: Towards a more holistic approach. Psychol Soc Educ. 2015;7(3):279. doi: 10.25115/psye.v7i3.519.

16. Gerken M, Beausaert S, Segers M. Working on professional development of faculty staff in higher education: Investigating the relationship between social informal learning activities and employability. Hum Resour Dev Int. 2015;19(2):135-51. doi: 10.1080/13678868.2015.1116241.

17. Wilkerson L, Irby DM. Strategies for improving teaching practices: A comprehensive approach to faculty development. Acad Med. 1998;73(4):387-96. doi:10.1097/00001888-199804000-00011. [PubMed: 9580715].

18. Sicat BL, O'Kane Kreutzer K, Gary J, Ivey CK, Marlowe EP, Pellegrini $\mathrm{JM}$, et al. A collaboration among health sciences schools to enhance faculty development in teaching. Am J Pharm Educ. 2014;78(5):102 doi: 10.5688/ajpe785102. [PubMed: 24954942]. [PubMed Central: PMC 4064479]

19. Camblin LD, Steger JA. Rethinking faculty development. High Educ 2000;39(1):1-18.

20. Hodgson CS, Wilkerson LA. Faculty development for teaching improvement. In: Steinert Y, editor. Development in the health professions a focus on research and practice. Dordrecht, Heidelberg, New York, London; 2014. p. 29-52. doi:10.1007/978-94-007-7612-8_2.

21. Gruppen LD, Frohna AZ, Anderson RM, Lowe KD. Faculty development for educational leadership and scholarship.Acad Med. 2003;78(2):13741. doi: 10.1097/00001888-200302000-00007. [PubMed: 12584091].

22. Kordestani Moghaddam A, Mirzazadeh A. Medical education scholars program: An approach to development of scholars in education in Tehran University of Medical Sciences. Adv Med EducPract. 2019;10:373-
8. doi: 10.2147/AMEP.S196424. [PubMed: 31239800]. [PubMed Central: PMC6554523].

23. Branch WJ, Chou CL, Farber NJ, Hatem D, Keenan C, Makoul G, et al. Faculty development to enhance humanistic teaching and role modeling: A collaborative study at eight institutions. J Gen Intern Med. 2014;29(9):1250-5. doi: 10.1007/s11606-014-2927-5. [PubMed: 24947051]. [PubMed Central: PMC4139513].

24. Frantz J, Rhoda A, Murdoch-Eaton DB, Sandars J, Marshall M, Burch VC. Understanding faculty development as capacity development: A case study from South Africa. Afr J Health Profes Educ. 2019;11(2):53. doi: 10.7196/AJHPE.2019.v11i2.1120.

25. Matsika A, Nathoo K, Borok M, Mashaah T, Madya F, Connors S, et al. Role of faculty development programs in medical education at the University of Zimbabwe College of Health Sciences, Zimbabwe. Ann Glob Health. 2018;84(1):183-9. doi: 10.29024/aogh.5. [PubMed: 30873802]. [PubMed Central: PMC6748263].

26. Farley H, Casaletto J, Ankel F, Young KD, Hockberger R. An assessment of the faculty development needs of junior clinical faculty in emergency medicine. Acad Emerg Med. 2008;15(7):664-8. doi: 10.1111/j.15532712.2008.00152.x. [PubMed: 19086214].

27. Colella M, Bisanzo M, Farquhar C, Nambaziira R, Carter E, Gimbel $S$, et al. Implementation and evaluation of an innovative leadership and teacher training program for non-physician emergency medicine practitioners in Uganda. Afr J Emerg Med. 2019;9(1):25-9. doi: 10.1016/j.afjem.2018.12.002. [PubMed: 30873348]. [PubMed Central: PMC6400005].

28. Daboval T, Ferretti E, Moussa A, van Manen M, Moore GP, Srinivasan $\mathrm{G}$, et al. Needs assessment of ethics and communication teaching for neonatal perinatal medicine programs in Canada. Paediatr Child Health. 2019;24(3):e116-24. doi: 10.1093/pch/pxy108. [PubMed: 31111831]. [PubMed Central: PMC6519660].

29. Walker RM, Lane LW, Siegler M. Development of a teaching program in clinical medical ethics at the University of Chicago. Acad Med. 1989;64(12):723-9. doi:10.1097/00001888-198912000-00007. [PubMed: 2590351]. 